MATEC Web of Conferences 48, 06004 (2016)

DOI: $10.1051 /$ matecconf $/ 20164806004$

(C) Owned by the authors, published by EDP Sciences, 2016

\title{
The status of world outlook and environmental competencies in aerospace engineering training: the general and special
}

\author{
Igor Ardashkin ${ }^{1, a}$, Alexander Bykov ${ }^{2}$ and Ekaterina Kirsanova ${ }^{1}$ \\ ${ }^{1}$ National Research Tomsk Polytechnic University, 634050 Tomsk, Russia \\ ${ }^{2}$ National Research Tomsk State University, 634050 Tomsk, Russia
}

\begin{abstract}
The article is devoted to the study of the status of philosophical and environmental competences for engineering education programs in the field of space exploration. The authors prove that the specialists who will work in the space field in the XXI century face the most important problems, the solution of which is vital for humanity. It is stated that the quality of future decisions will be determined by the development of the philosophical and environmental ideas. It is demonstrated that these idea should necessarily have futurological character. It is suggested that the special courses aimed at the formation of futurological philosophical and environmental concepts can present as a possible solution to this problem (e.g. Creativity training for engineers, etc.).
\end{abstract}

\section{Introduction}

Nowadays space is one of the most important areas for scientific knowledge and the development of human civilization. The future of humanity is largely determined by the level of prospective success of space development. Space has enormous latent possibilities, penetration into of which is not just a cognitive interest but vital task for human civilization that determines the fate of it. Especially, today when humanity is on the threshold of space interaction new phase (industrial exploration) [1]. It is connected with the development of consecutive penetration into space, and with the research of evolutionary processes of global scale. Obviously, the processes that occur on our planet and lead to the emergence of serious global problems (global warming, nutrition problems, poverty, ecological disruption etc.) require the appropriate supervision and management, the transformation of these processes from a class of dangerous for life and social activity to a class of neutral or advancing the conditions of human existence and society.

To solve the above mentioned problems, it is important to develop projects of space exploration, estimating space not only as the scope of scientific research, but also as the sphere of economic and social potentials. Due to this, it is necessary to establish the subject oriented educational programs in higher educational institutions. This does not mean that such specialists are not trained nowadays in various universities around the world, but it is expected that the quality of such educational programs meets the needs of latest challenges of the time, the essence of which was mentioned above [2].

Russia has wide experience of personnel training for space industry. This experience can be represented as one of the leading in the world, taking into account the achievements in the field of

\footnotetext{
${ }^{\mathrm{a}}$ Corresponding author : ibardashkin@tpu.ru
} 
space exploration in our country. But today, there are several problems in this area connected with the lack of specialists for enterprises providing the activity of space industry. Usually these problems are related to an age gap of specialists (when very young professionals aged from 22-23 years and very senior professionals over the age of 60 years work together), to loss of work attractiveness in the space industry for economic and social reasons, to the degree of image and to the reform of educational standards etc.

With a glance to the current situation it is necessary to appeal to the quality of personnel training for the space industry on the example of Russian Federation. Moreover, the authors try to focus primarily on determination of role and importance of philosophical and environmental competences, believing that the development of these abilities of future experts will determine the quality of their training in general $[3,4]$. This interconnection is, primarily, reasoned by the specifics of cosmic sphere - the space that is the most different from the life conditions of our planet, and therefore it represents for people (humanity), the habitat, features and functions of which absolutely other than our usual terrestrial conditions of existence. Hence, the experts who are preparing to explore, to investigate and to be in outer space should take into account as much as possible its specific features in their professional activities, and the task of education, in particular, is to form such competences [5].

\section{Results and discussion}

Appeal to the issue of the status assessment of philosophical and environmental competences of space exploration of engineering training is determined by several aspects. These aspects are of the different nature: philosophical, cognitive, socio-economic, legislative, environmental, technological, etc.

The main aspect of updating of this topic is current situation on our planet, which is fatal for humanity. The solution of existing and actively growing problems is impossible without active exploration and development of outer space [6,7]. With it can be connected the identification of approaches to address critical issues of our time. It must be obvious that research in this field has a radically different character and origin, than conventional research on the Earth. For these reasons, research requires a completely different approach due to the fact that a researcher is in a situation of critical uncertainty and cannot always clarify what is happening, especially when describing it in terms of the existing research. Often, some phenomena can be neglected by scientists due to the fact that they do not consider them noteworthy. The situation can often resemble the reality of a fairy tale, where the researcher is required to «go somewhere and to bring something». This reason is more of philosophical nature and is the most general in comparison with other reasons. That, however, does not set aside the necessity to indicate them.

Another aspect of the appeal to the status assessment of philosophical and environmental competences of engineering training of space exploration stems from the first one, but it has independent significance. This is an aspect of cognitive character. The cognitive aspect distinguishes the specificity of human cognitive practice, draws attention to the organization of cognitive process. The fact is that a person within the boundaries of existing terrestrial space, in the process of scientific knowledge usually had to deal with the study objects, available to his perceptive apparatus. In the cognitive sciences, this type of object was named human-dimensional. But when people started to investigate, the microworld (quantum reality) on the one hand, and, they discovered megaworld (space and the universe) on the other hand, then the question about the perception of these worlds arose, because these objects of cognition became non dimensional for human. In order to cognize, to imagine this type of reality a person had to fall back upon to all the efforts, going beyond his empirical possibilities. This reality has been transformed into a mathematical formula, or fantastic images, unrelated to understandable and accessible meanings. This reality was of paradoxical nature. Moreover, in the cognitive sense, the problem of the Unity of the world started to manifest, which was previously testified by scientific principles obtained in physics, (in particular, Heisenberg's uncertainty principle, Bohr's principle of complementarity, etc.). 
Many researchers even started to speak about the formation of a new type of thinking, which began to reflect all the above mentioned transformations. It is proposed to call this type cosmic. Particularly, according to Russian researcher L.V. Shaposhnikova, "new cosmic thinking requires a different system of cognition and other methodological foundations different from those that exist in modern theories of knowledge. Understanding and establishing the new system, there is an urgent need for further development of cosmic thinking ... Space in the context of new thinking is considered, not only as an astronomical concept, but in all its energy wealth and diversity of states of matter ... This system of knowledge will be closely connected with the moral and ethical issues ... Cosmic thinking includes a new approach to the study of human problems as a cosmic structure in which the phenomenon of consciousness is an important evolutionary orientation" $[8,9]$.

We may not agree with the name of a new type of thinking, we may supplement its existing features with others, but we cannot deny the need of these changes. And the fact that the things which were identified there as nontraditional features of cognitive processes has a frivolous nature, because in this article it is important to indicate this trend without its detailed analysis.

Accordingly, these cognitive transformations cannot be ignored nowadays while engineers training related to the space industry.

A third aspect of status assessment of philosophical and environmental competences of engineering training in the field of space is the fact that today humanity has launched a new stage - the stage of industrial development of space associated with the need to use space resources, outer space, energy, etc. for the benefit of humanity. This assessment is also confirmed in literature.

Particularly, S.V. Krichevsky points out that "at the present time in the field of space activity the transition to the industrial stage is carried out. This stage is represented by the creation of global space systems and technical infrastructure in space, by the solution of vital for humanity actual and future practical tasks of extraterrestrial resources exploration. In this regard, Russia and world community should develop and implement adequate policy (cosmic, scientific, technical, economic, environmental), aimed at natural resources management and natural environment protection in order to ensure sustainable and safe development. This requires the establishment and implementation of appropriate "laws of the game" and administration systems, covering the totality of corresponded relations [7].

Such branch of development should be related to the two previously presented aspects as long as industrial exploration of space must have a fundamentally different nature than its realization on the Earth. Space should become an integrating factor for humanity, should contribute to understanding of the unity of mankind in social and economic development of space. Without this condition it is very difficult to imagine the future of humanity, because if those existing nowadays issues of political, economic, social, religious and ethnic nature remain in the process of space industrialization, it will have a negative impact on the fate of our civilization in general. This integration is needed not only because of ethical and moral reasons associated with a sense of responsibility for their own destiny, but also because of the fact that no country is able to develop and maintain the technological component of industrial space exploration individually. All countries, societies and cultures should contribute to this process, without mutual efforts the process will be impossible. The experience of the international space station clearly demonstrates it [6].

Legal aspect plays important role in the issue of status updating of philosophical and environmental competences of engineering training in space exploration. The fact is that today, the space serves as a place, which is accessible to absolutely every one of our planet, because space expanses are not legally fixed. At the present moment it facilitates the process of space exploration, but if there is an incoordination between the countries about the conditions and rules of exploration and work in space, this legal void can play a negative role. Therefore, aspects of the legal regulation of space exploration are essentially significant and this should be reflected in consciousness of experts, whose professional activity is connected with space. In addition, the integration of human communities on the Earth facing the necessity of space exploration will be more solid if it is carried out on a legal basis, if it governed by legal mechanisms.

The ecological aspect also plays an important role in status assessment of philosophical and environmental competences of engineering training in space exploration. Also it is significant because 
in relation to space environmental issues play a dual-use role. Firstly, these aspects are extremely important for the planet, which is experiencing the effects of the most powerful pollution of its history and ecological disruption. Secondly, penetrating into space, humanity risks repeating the negative experience in the new space, which seems, though infinite, but unpolluted. It does not dispense with the necessity of awareness of the problem in time (especially that even nowadays near-Earth space is contaminated enough by so-called "space junk").

According to S.V. Krichevsky, "regulation of extra-terrestrial natural environment is clearly lagging behind space activity that is growing on a set of directions and dimensions, including those already outside the near-Earth space environment (for example, in connection with landings to Mars and plans of its colonization). This reflects not only formal legal relationships, but also an outlook and psychology of people on space activities in extraterrestrial natural environment" [7].

The repercussions of these aspects affect the system of engineering education that is pointed out by many foreign experts. In particular, J. Halb, J. Adamovsky, K. Paul-Vosty state, «this nature of the engineering method is also reflected in the evolution of engineering curricula. In recent years, traditional engineering education in such areas as material science and construction has been complemented with education in ecology, economics, stakeholder participation or ethics in order to react to new challenges in the engineering profession.

One of the more recent challenges in engineering practice and education is the consideration of sustainable development issues (as well as related issues such as climate change, increasing complexity, etc.). Sustainable engineering comprises a life-cycle perspective and consideration of ecological, economic, and socio-cultural aspects [10].

It is obvious that remaining technological aspect of philosophical and environmental competences of engineering training in space exploration should converge all other presented aspects in space engineering and technology development [11]. It is essential that trained expert in the field of space exploration really gets through the mastery of philosophical and environmental competence the image of the area where he has to work. These aspects related to the ideological and environmental competences of educational programs may be described as futuristic as they all involve a certain "flash-forward" into the future, the ability to see something, which does not exist yet, that, how equipment and technology of new type can operate in uncertain conditions.

It is analyzed needs that make us apply to educational standards relating to the preparation of specialists for cosmic sphere in order to find out if they have competences required. To be objective, let us consider the standards of different levels of Bachelor's program (161100 "Guidance, navigation and control"), Specialist's program (160400 "Design, production and operation of rockets and spacerocket complexes"), Master's program (160400 "Missile Systems and Space") [12-14]. The educational standard of bachelor educational program includes 16 general cultural competences, specialist's program - 17 general cultural competences, the standard of master's program - 17 general cultural competences. If you compare the content of these competences with the content of similar competences, but of the standards of other engineering programs not related to space exploration, you can find out that contents are almost identical (e.g. 140400 Power and Electrical Engineering (Bachelor) 130101 Applied Geology (specialty), 04.15.01 Mechanical Engineering (Master)) [15-17]. This means that the futurist aspect of philosophical and environmental competences of the preparation of specialists in the field of space exploration is not taken into account [18].

According to the authors of this article, this is an important omission because the fate of mankind and the earth civilization depend on the activity of the future specialists to a large extent. In this article the authors are not ready to offer a full set of competences of futurological plan, but they are ready to name several options for a possible solution of this problem. In particular, in 2016 within the educational bachelor program of Tomsk Polytechnic University the course "Creativity training for engineers" was introduced. One of the most important tasks of it is the development of creative competences, imagination of students within the framework of above mentioned futurological format. If students do not generate images of reality beyond the ordinary boundaries, if they are not forced to look for unorthodox solutions, then during their professional activities they will not be able to find necessary engineering solutions, especially when it comes to the scope of space. It is possible to offer a similar course aimed at developing the environmental competencies, which will focus on the 
development of ecological concepts and skills of extraterrestrial type (for example, extraterrestrial space ecology).

To confirm this idea, we would like to appeal to historical analogy related to the development of space industry in our country. Russia (USSR) launched the first artificial satellite into space, the first man, they first came out in outer space, etc. not only because enormous financial, material and human resources were used, but also because, long before these events in our country new direction called Russian cosmism was widely practiced. For contemporaries the ideas of N.F. Fedorov, K.E. Tsiolkovsky, V.I. Vernadsky and others seemed especially inexplicable and inapplicable, fantastic, but with the help of them people were forced to think about the connection of the Earth and space, about the possibility of penetrating into space. As noted by L. Margulis, D. Sagan, "it is impressive how Vernadsky erased rigid distinction between living organisms and inanimate environment, describing life globally, even before the first images of the Earth surface from space. In fact, Vernadsky created for the space the same thing as Darwin for the time: as Darwin showed that life arose from a common ancestor, so Vernadsky showed that life is "built-in" in unbreakable indissoluble material - biosphere. Life is a community processing energy from the sun into earth substance" [19].

\section{Conclusion}

To conclude with, it should be noted that the status of philosophical and environmental competences of engineering training of specialists in the field of space exploration will play one of the defining roles. This conclusion is due to the nature of the professional activity of such specialists, according to which they will prepare the technological developments and solutions to an environment that is radically different from the Earth. Therefore, futurist aspect of philosophical and environmental competences of future experts will have to determine the nature of their futuristic technological solutions and developments. As one of the possible ways in order to form such competences the authors propose to organize special courses aimed at creating futurological context of educational preparation (e.g. Creativity training for engineers).

\section{Acknowledgement}

The article is supported by the Russian Humanitarian Science Foundation grant.

\section{References}

1. B. S. Caldwell, Act. Astr. 112 (2015)

2. J. Rodriguez, A. Laveron-Simavilla, J.-M. del Cura, J. M. Ezquerro, V. Lapuerta, M. CorderoGracia, Adv. In Sp. Res. 56, 7 (2015)

3. S.P. Kurdyumov, Mater. mezhd. nauch.-obshch. konf. 1 http://lib.icr.su/node/877

4. G.D. Dulnev, Mater. mezhd. nauch.-obshch. konf. 1 http://lib.icr.su/node/885

5. B. Donald, Act. Astr. 107 (2015)

6. P. Dias, Scien. and Engin. Ethic. 20, 2 (2014)

7. T. Thumm, J.A. Robinson, Act. Astr. 103 (2014)

8. S.V. Krichevskiy, Osvoenie vnezemnykh prirodnykh resursov I okhrana okruzhayushchey sredy. Upravlenie sotsioprirodnymi sistemami: filosofsko-metodologicheskie aspekty (Rossiyskiy arkhiv gosudarstvennykh standartov, Moscow, 2006)

9. L.V. Shaposhnikova, Mater. mezhd. nauch.-obshch. konf. 1 http://lib.icr.su/node/876

10. I.B. Ardashkin, L.A. Korobeynikova and A.V. Popova, Mat. Web of Conf. 37 (2015)

11. J. Halbe, J. Adamowski, C. Pahl-Wostl, Jour. of Clean. Prod. 106 (2015)

12. R. Correal, G. Pajares, J.J. Ruz. Robot. 34, 2 (2016)

13. Prikaz ob utverzhdenii federalnogo gosudarstvennogo obrazovatelnogo standarta vysshego obrazovaniya po napravleniyu podgotovki 161100 Sistemy upravleniya dvizheniem I navigatsiya. 


\section{MATEC Web of Conferences}

http://www.consultant.ru/document/cons_doc_LAW_192521/2ff7a8c72de3994f30496a0ccbb1dd afdaddf518/ (2016)

14. Prikaz ob utverzhdenii federalnogo gosudarstvennogo obrazovatelnogo standarta vysshego obrazovaniya po napravleniyu podgotovki 160400 Proektirovanie, proizvodstvo i ekhspluatatsiya raket I raketno-kosmicheskikh kompleksov. http://www.edu.ru/db-mon/mo/Data/d_11/m82.pdf (2016)

15. Prikaz ob utverzhdenii federalnogo gosudarstvennogo obrazovatelnogo standarta vysshego obrazovaniya po napravleniyu podgotovki 160400 Raketnye kompleksy I kosmonavtika. http://www.consultant.ru/document/cons_doc_LAW_98340/5d5349cf7e1bf3869c85e8494a0df91 25b321608/ (2016)

16. Prikaz ob utverzhdenii federalnogo gosudarstvennogo obrazovatelnogo standarta vysshego obrazovaniya po napravleniyu podgotovki 140400 Elektroenergetika I elektrotekhnika. http://www.edu.ru/db-mon/mo/Data/d_09/prm710-1.pdf (2016)

17. Prikaz ob utverzhdenii federalnogo gosudarstvennogo obrazovatelnogo standarta vysshego obrazovaniya po napravleniyu podgotovki 130101 Prikladnaya geologiya. http://www.edu.ru/dbmon/mo/data/d_11/prm62-1.pdf (2016)

18. Prikaz ob utverzhdenii federalnogo gosudarstvennogo obrazovatelnogo standarta vysshego obrazovaniya po napravleniyu podgotovki 15.04.01 Mashinostroenie. http://cdnimg.rg.ru/pril/107/88/52/35179.pdf (2016)

19. I.B. Ardashkin, A.N. Yakovlev, N.V. Martyushev, Adv. Mat. Res. 1040 (2014)

20. L. Margulis, D. Sagan, Chto takoe zhizn? V.I. Vernadskiy: Pro et Contra (Russkiy christianskiy gumanitarnyy institut, St-Petersburg, 2000) 